\title{
Yellow Passion Fruit Seed Oil (Passiflora edulis f. flavicarpa): Physical and Chemical Characteristics
}

\author{
Cassia Roberta Malacrida* and Neuza Jorge \\ Departamento de Engenharia e Tecnologia de Alimentos; Universidade Estadual Paulista Júlio de Mesquita Filho; \\ Rua Cristóvão Colombo, 2265; 15054-000; São José do Rio Preto - SP - Brasil
}

\begin{abstract}
The aim of this study was to determine the chemical composition - physico-chemical properties, fatty acid and tocopherol compositions and total phenolic compounds - and evaluate the radical-scavenging activity of crude oil extracted from passion fruit (Passiflora edulis $f$. flavicarpa) seeds, aiming to use the agro-industrial by-products. The oil seed extraction was performed by Soxhlet method and the oil yield from the seeds was 30.39\%. The oil showed high levels of unsaturated fatty acids (87.59\%), including mainly linoleic (73.14\%) and oleic (13.83\%) acids, tocopherol (499.30 mg/kg) and phenolic compounds (1,314.13 mg GAE/kg). The physico-chemical characteristics were similar to those of other edible oils and the oil showed significant antioxidant activity. Therefore, the potential utilization of the passion fruit seed oil as a raw material for food, chemical and pharmaceutical industries could be favorable.
\end{abstract}

Key words: Passiflora edulis, seed oil; fatty acids, tocopherols, phenolic compounds

\section{INTRODUCTION}

Passion fruit belongs to the Passifloraceae family and is originally from the tropical America, featuring over 500 species worldwide. Among these, the fruits of only about 20 varieties are edible and the most cultivated species in the world are the yellow passion fruit (Passiflora edulis f. flavicarpa), purple passion fruit (Passiflora edulis) and sweet passion fruit (Passiflora alata) (Fraife Filho et al. 2010). However, a single species, the yellow passion fruit, is grown in $95 \%$ of orchards (Meletti et al. 2005).

The yellow passion fruit is mainly marketed in natura, and used to prepare the ice creams, soft drinks, candies, among others. However, the use of the industrialized passion fruit juice has been increasing in the consumer market. In juice industry, the passion fruit yields thousands of tons of seeds as agricultural by-products during juice extraction. It is estimated, for example, that the residue from the production of passion fruit juice reaches $40 \%$ of the amount of processed fruits. About $90 \%$ of the waste is made of shells and seeds (Lousada Júnior et al. 2006). The seeds, containing large amounts of fiber and oil are generally disposed after being crushed. These residues imply operating costs for the industries and may become an environmental problem. Thus, the extraction of oil from the passion fruit seeds may add value to this agro-industrial waste.

Besides the unsaturation degree and fatty acid composition, characterizing the compounds in the unsaponifiable matter, such as tocopherols, carotenoids, phenolic compounds, among others, is of vital importance when it comes to indicate the possible technological applications of the oils in food, chemical or pharmaceutical industries.

\footnotetext{
*Author for correspondence: cmalacrida@terra.com.br
} 
Furthermore, vegetable oils contain the substances with antioxidant properties. Besides preventing the lipids oxidative deterioration, antioxidants act as a benefit for the health, preventing aging-related diseases such as cancer and heart diseases (Sousa et al. 2007). Although some studies have reported the chemical compositions of oils extracted from the seeds of different varieties of passion fruit (Ferrari, Colussi and Ayub 2004; Nyanzi, Carstensen and Schwack 2005; Piombo et al. 2006), no study has been carried out on the antioxidant activity of this oil.

This study was carried out to chemically characterize the crude oil extracted from the yellow passion fruit seeds and to evaluate their antioxidant properties, aiming at a better utilization of the seeds from the agro-industrial waste and the possible applicability of this seed oil in the food, chemical and pharmaceutical industries.

\section{MATERIALS AND METHODS}

\section{Oil extraction}

Mature passion fruits (Passiflora edulis f. flavicarpa) were purchased from the retail market in São José do Rio Preto - São Paulo, Brazil. Five batches were obtained at different harvest periods. Each batch, weighing $3 \mathrm{~kg}$, was obtained at intervals of approximately 45 days during the harvest. The seeds were manually removed from the fruits, lightly washed with distilled water and dried at room temperature for approximately two weeks. The seeds were then packed in black polyethylene recipients, sealed and stored at room temperature until they were used. Before the oil extraction experiments, five seeds batches were homogenized all together in order to constitute only one.

The passion fruit seed oil was obtained by extraction with petroleum ether at $40-60^{\circ} \mathrm{C}$ using a Soxhlet extractor for six hours. After extraction, the solvent was evaporated under reduced pressure at $60^{\circ} \mathrm{C}$. The obtained oil was kept in amber glass bottles, flushed with nitrogen stream, sealed and stored in a freezer $\left(-18^{\circ} \mathrm{C}\right)$.

\section{Proximate composition of the seeds}

Moisture, lipid and ash contents of passion fruit seeds were determined by following the standard AOCS methods (1993). Proteins were quantified by the Kjeldahl procedure, using the general factor
(6.25) to calculate the total protein (AOAC 1995). Carbohydrates and fibers contents were calculated by subtracting the sum of the percentages of moisture, lipids, protein and ash from 100\%.

\section{Physico-chemical characterization of seed oil}

To determine the refractive index $\left(40^{\circ} \mathrm{C}\right)$, iodine value $\left(\mathrm{g} \mathrm{I}_{2} / 100 \mathrm{~g}\right)$, saponification value $(\mathrm{mg}$ $\mathrm{KOH} / \mathrm{g})$, free fatty acids (\%, in oleic acid), acid value $(\mathrm{mg} \mathrm{KOH} / \mathrm{g})$ and peroxide value (meq peroxide $/ \mathrm{kg}$ ), standard AOCS methods (1993) were followed. Unsaponifiable matter was quantified according to the method described by Hartman and Esteves (1982). The oxidative stability index was determined by the use of a Rancimat instrument (Metrohm Ltd., Herisau, Switzerland) following AOCS method (1993). Oxidation was carried out at $100^{\circ} \mathrm{C}$ with an airflow rate of $20 \mathrm{~L} / \mathrm{h}$. The oxidative stability index was defined as the hours for the oil sample to develop a measurable rancidity.

\section{Fatty acid composition}

The fatty acid composition was analyzed by using the gas-liquid chromatography after transesterification. The fatty acid methyl esters (FAME) were prepared according to the procedure described by Hartman and Lago (1973). In a 50 $\mathrm{mL}$ flask provided with air condenser, $200 \mathrm{mg}$ of the oil was saponified with $5 \mathrm{~mL}$ of $0.5 \mathrm{~N}$ methanolic solution of potassium hidroxide by boiling for 3 minutes. To the hot solution, $15 \mathrm{~mL}$ of ammonium chloride/sulphuric acid in methanol was added and refluxed for about 3 minutes. Subsequently, it was transferred into a separating funnel using $10 \mathrm{~mL}$ of $\mathrm{n}$-hexane and $50 \mathrm{~mL}$ of $10 \%$ sodium chloride solution. After the layers were separated, the n-hexane layer was collected. The analyses of the FAMEs were performed with a Varian (Walnut Creek, USA) gas-liquid chromatograph, GC 3900 model, equipped with a flame-ionization detector, a split-splitless injector and an autosampler. The FAMEs were separated by the use of a CP-Sil 88 fused silica capillary column $(50 \mathrm{~m}$ length, $0.25 \mathrm{~mm}$ internal diameter and $0.20 \mu \mathrm{m}$ film thickness). The column oven temperature was initially held at $50^{\circ} \mathrm{C}$, for 2 minutes, heated at $4{ }^{\circ} \mathrm{C} / \mathrm{min}$ up to $240^{\circ} \mathrm{C}$ and maintained at $240^{\circ} \mathrm{C}$ for 20.5 minutes. The injector and detector temperatures were 230 and $250^{\circ} \mathrm{C}$, respectively. Samples of $1.0 \mu \mathrm{L}$ were injected, adopting a split ratio of 1:50. The carrier gas was 
hydrogen, with a $30 \mathrm{~mL} / \mathrm{min}$ flow rate. FAMEs were identified by comparing their retention times to those of pure FAME standards (Supelco, Bellefonte, USA) under the same operating conditions. The integration software computed the peak areas and percentages of fatty acid methyl esters were obtained as weight percentage by direct internal normalization.

\section{Tocopherol profile}

The tocopherol composition of the passion fruit seed oil was determined by using the high performance liquid chromatography (HPLC). Prior to the HPLC analysis, the seed oil was diluted with hexane $(0.4: 10 \mathrm{w} / \mathrm{w})$ and $20 \mu \mathrm{L}$ samples were injected. The samples were analyzed with a Varian (Walnut Creek, USA) HPLC, Pro-Star model, equipped with a fluorescence detector. The operating conditions of fluorescence detector were $\lambda$ excitation $290 \mathrm{~nm}$ and $\lambda$ emission $330 \mathrm{~nm}$. A normal phase column (Microsorb $100 \mathrm{Si}, 250 \mathrm{~mm}$ x $4.6 \mathrm{~mm}$ internal diameter with $0.5 \mu \mathrm{m}$ particle size) was used with hexane/isopropanol $(99.5 / 0.5$ $\mathrm{v} / \mathrm{v})$ as a mobile phase. The system was operated isocratically at a $1.2 \mathrm{~mL} \mathrm{~min}{ }^{-1}$ flow rate. The identification of tocopherols $(\alpha, \beta, \gamma$ and $\delta$ tocopherol) was conducted by comparing the HPLC retention time to those of standard compounds (Supelco, Bellefonte, USA) under the same operating conditions. The quantification of tocopherols was based on the external standard curves of standard $\alpha, \beta, \gamma$ and $\delta$-tocopherol solutions, within the range of $1-5 \mu \mathrm{g} / \mathrm{ml}$.

\section{Total phenolic compounds}

The content of the total phenolic compounds in the methanolic extracts was determined by the FolinCiocalteu method (Singleton and Rossi 1965). One gram of oil was measured into a test tube and then $3.0 \mathrm{~mL}$ of methanol was added. The test tube was vortexed and then centrifuged at $3.000 \mathrm{rpm}$ for 10 minutes and the supernatant was collected. This procedure was repeated twice more. All the three extractions were combined and the final volume was made to $10 \mathrm{~mL}$ with the extraction solvent. An aliquot $(0.1 \mathrm{~mL})$ of methanolic extract was placed in a volumetric flash $(10 \mathrm{~mL})$ and FolinCiocalteau reagent $(0.5 \mathrm{~mL})$ was added. After 3 minutes, saturated sodium carbonate $(1.5 \mathrm{~mL})$ was added. The flask was filled with water up to 10 $\mathrm{mL}$. After 2-h reaction at room temperature, the absorbance was read at $765 \mathrm{~nm}$ against a reagent blank using a UV-vis spectrophotometer (Shimadzu, Kyoto, Japan). Quartz cuvettes $(1 \mathrm{~cm})$ were used for visible absorbance measurements. Calibration was performed using gallic acid (Sigma-Aldrich, St Louis, EUA) and a calibration curve was prepared in the range 0 to $500 \mathrm{mg} / \mathrm{L}$.

\section{Antioxidant activity}

DPPH scavenging capacity of passion fruit seed oil was determined according to the previously reported procedure using the stable 2,2-diphenyl1-picryhydrazyl radical $\left(\mathrm{DPPH}^{\circ}\right)$ (Kalantzakis et al. 2006). This method consisted of spectrophotometric measurement of the intensity of color change in solution, depending on the amount of $\mathrm{DPPH}^{\circ}$. The reaction was initiated by mixing $1 \mathrm{ml}$ of the oil, previously diluted with ethyl acetate $(1: 10 \mathrm{w} / \mathrm{w})$, with $4 \mathrm{~mL}$ of $\mathrm{DPPH}^{\circ}\left(10^{-}\right.$ $\left.{ }^{4} \mathrm{M}\right)$. The mixture was vigorously shaken and able to stand for $30 \mathrm{~min}$; the resulting solution absorbance was measured at $517 \mathrm{~nm}$ using a UVvis spectrophotometer (Shimadzu, Kyoto, Japan). Quartz cuvettes $(1 \mathrm{~cm})$ were used for absorbance measurements. The amount of sample needed to decrease the initial DPPH concentration by $50 \%$ $\left(\mathrm{EC}_{50}\right)$ was calculated graphically by plotting the percentage of remaining $\mathrm{DPPH}^{\circ}$, estimated according to a standard curve, against sample concentrations $(10,25,50,75$ and $100 \mathrm{mg} / \mathrm{mL})$. The passion fruit seed oil antiradical power (ARP) was calculated as $1 / \mathrm{EC}_{50}$ (Brand-Williams, Curvelier and Berset 1995).

\section{Statistical analysis}

The passion fruit seed oil extraction experiments were repeated six times and the obtained oils were combined. The analysis was performed based on three replicates and the mean values and standard error were calculated.

\section{RESULTS AND DISCUSSION}

According to the passion fruit seed composition (Table 1), the lipid content was $30.39 \%$, indicating that these seeds were a good oil source, especially when compared to soybean seed, which contained about 20\% lipids (Bailey 1996).

The passion fruit seeds protein percentage $(12.23 \%)$ was comparable to that found in some cereal grains such as corn $(10.2 \%)$, oats $(11.3 \%)$ and wheat (12.2\%) (Lásztity 1996). Moreover, the 
passion fruit seeds showed high percentage of carbohydrates + fiber $(48.73 \%)$. According to Chau and Huang (2004), passion fruit seeds contained $64.8 \%$ of total fiber in their composition, providing an alternative source of fiber.

Table 1 - Proximate composition of dry passion fruit seeds.

\begin{tabular}{lc}
\hline Proximate composition & Values $^{(\%)^{\mathbf{1}}}$ \\
\hline Moisture & $7.38 \pm 0.07$ \\
Lipid & $30.39 \pm 0.04$ \\
Protein & $12.23 \pm 0.28$ \\
Ash & $1.27 \pm 0.02$ \\
Carbohydrate and fiber $^{2}$ & 48.73 \\
\hline
\end{tabular}

${ }^{1}$ Mean value \pm standard error $(n=3)$.

${ }^{2}$ Calculate by difference.

The refractive, iodine and saponification values and the percentage of unsaponifiable matter in the passion fruit seed oil (Table 2) were consistent with those found for the conventional oils such as soybean and corn (Codex Alimentarius Commission 2008). According to the iodine value, the passion fruit seed oil could be classified as semi-siccative (iodine value between 115 and 130 $\mathrm{g} \mathrm{I}_{2} / 100 \mathrm{~g}$ ), indicating its possible use in the food and chemical processing.

The good quality of passion fruit seed oil can be verified by the low acid and peroxide values, which are related to the development of hydrolytic and oxidative reactions, respectively. The Codex Alimentarius Commission (2008) has defined a maximum acid value of $4.0 \mathrm{mg} \mathrm{KOH} / \mathrm{g}$ for crude oils and maximum peroxide values of 10 and 15 meq $/ \mathrm{kg}$ to crude and refined oils, respectively, as quality parameters. The passion fruit seed oil presented acid and peroxide values below these standards.

Table 2 - Physico-chemical characteristics of passion fruit seed oil.

\begin{tabular}{lccc}
\hline \multirow{2}{*}{ Characteristics } & \multirow{2}{*}{ Values $^{1}$} & \multicolumn{2}{c}{ Literature values $^{2}$} \\
\cline { 3 - 4 } & & Soybean & Corn \\
\hline Refractive index $\left(40^{\circ} \mathrm{C}\right)$ & $1.4682 \pm 0.0001$ & $1.466-1.470$ & $1.465-1.468$ \\
Iodine value $\left(\mathrm{g} \mathrm{I}_{2} / 100 \mathrm{~g}\right)$ & $128.0 \pm 0.75$ & $124-139$ & $103-135$ \\
Saponification value $(\mathrm{mg} \mathrm{KOH} / \mathrm{g})$ & $190.7 \pm 2.76$ & $189-195$ & $187-195$ \\
Unsaponifiable matter $(\%)$ & $1.51 \pm 0.08$ & $\leq 1.5$ & $\leq 2.8$ \\
Free fatty acids $(\%)$ & $1.18 \pm 0.03$ & & \\
Acid value $(\mathrm{mg} \mathrm{KOH} / \mathrm{g})$ & $2.35 \pm 0.06$ & & \\
Peroxide value $(\mathrm{meq} / \mathrm{kg})$ & $1.46 \pm 0.03$ & & \\
Stability oxidative $(\mathrm{h})$ & $7.89 \pm 0.18$ & & \\
${ }^{1}$ Mean value \pm standard error $(\mathrm{n}=3)$. & & & \\
${ }^{2}$ Codex Alimentarius Commission $(2008)$. & & &
\end{tabular}

The oxidative stability obtained in this work for the passion fruit seed oil was relatively low, compared to the values recorded by Del Ré (2003) in soybean oil (12.47 h) and sunflower (10.01 h) at $100^{\circ} \mathrm{C}$ temperature.

The linoleic, oleic, palmitic and stearic were the most found fatty acids in the extracted oil (Table 3). This fatty acid profile, which is composed of a high percentage of unsaturated fatty acids and a low percentage of saturated fatty acids, is considered to be ideal for edible oils, indicating the possible use of passion fruit seed oil in cooking, as salad oil or in the margarine formulation. The quality and digestibility of edible vegetable oils are determined by the amount and composition of unsaturated fatty acids. The seed oil contained two essential fatty acids (linoleic and linolenic acid) but the content of linoleic acid $(73.14 \%)$ was by far higher than the linolenic acid $(0.41 \%)$. The linoleic fatty acid was predominant 
in passion fruit seed oil analysed by other authors: 68.68-70.06\% (Sant'Anna, Tôrres and Porto 2001) and $72.69 \%$ (Liu et al. 2008). The presence of linoleic acid at appropriate levels is crucial, since it is an essential fatty acid.

Comparing the total saturated and unsaturated fatty acids ratio in this study to those reported by Borges et al. (2007) for the common oils such as peanut, corn and soybeans, it was found that the passion fruit seed oil (1/7.06) presented a profile similar to corn oil (1/6.70). Dubois et al. (2007) ranked vegetable oils according to their fatty acid composition. Based on this classification, the passion fruit seed oil belonged to the polyunsaturated oil class, containing oleic and linoleic acids in greater quantities. This class includes a large amount of vegetable oils such as corn, sunflower, wheat germ and sesame.

Table 3 - Fatty acid composition of passion fruit seed oil.

\begin{tabular}{lc}
\hline Methyl esters & Values $(\boldsymbol{\%})^{\mathbf{1}}$ \\
\hline Miristic (C14:0) & Tr \\
Palmitic (C16:0) & $9.73 \pm 0.01$ \\
Palmitoleic (C16:1) & $0.11 \pm 0.01$ \\
Margaric (C17:0) & $\mathrm{Tr}$ \\
Stearic (C18:0) & $2.58 \pm 0.01$ \\
Oleic (C18:1 n-9) & $13.83 \pm 0.04$ \\
Linoleic (C18:2n-6) & $73.14 \pm 0.05$ \\
Linolenic (C18:3n-3) & $0.41 \pm 0.00$ \\
Araquidic (C20:0) & $0.10 \pm 0.01$ \\
Eicosenoic (C20:1) & $0.10 \pm 0.00$ \\
Behenic (C22:0) & $\mathrm{Tr}$ \\
UFA & 87.59 \\
MUFA & 14.04 \\
PUFA & 73.55 \\
SFA & 12.41 \\
SFA/UFA & $1 / 7.06$ \\
\hline
\end{tabular}

${ }^{1}$ Mean value \pm standard error $(n=3)$.

UFA: unsaturated fatty acids; MUFA: monounsaturated fatty acids; PUFA: polyunsaturated fatty acids; SFA: saturated fatty acids.

Studies on the fatty acids and sterol profiles of passion fruit seed oil, as well as its use for human consumption assessed the quality of dietary oil in rats. No changes in the metabolism of these animals were observed, leading to the conclusion that the oil could be used for edible purposes (Gaydon and Ramanoelina 1983).

Besides being used in food industry, oils containing high polyunsaturated fatty acid percentages, such as passion fruit seed oil, are commonly used as skin and hair conditioning agents and in the compositions of make-up products. Another current trend is the use of vegetable oils for biodiesel production, especially those derived from waste. Considering the seed oil amount and the fatty acid composition, the use of oil for biodiesel production may be viable.
The major tocopherols in the passion fruit seed oil were $\gamma$ - and $\delta$-tocopherol (Table 4). Although the $\delta$-tocopherol has been found naturally in small concentrations in lipids, it was the predominant tocopherol $(278.70 \mathrm{mg} / \mathrm{kg})$ in the passion fruit seed oil. The $\delta$-tocopherol concentration found in passion fruit seed oil was higher than that found in peanut $(13.4 \mathrm{mg} / \mathrm{kg})$, sunflower $(9.2 \mathrm{mg} / \mathrm{kg})$ and canola $(6.1 \mathrm{mg} / \mathrm{kg}$ ) oils (Tuberoso et al. 2007). Piombo et al. (2006) analyzed the tocopherols composition in the oils extracted from passion fruit (Passiflora edulis) seeds and found 217 and 243 $\mathrm{mg} / \mathrm{kg}$ for $\gamma$ - and $\delta$-tocopherol, respectively. However, the $\beta$-tocopherol was detected only in trace quantity. 
Table 4 - Tocopherol composition, total phenolic content and antioxidant activity of passion fruit seed oil.

\begin{tabular}{lc}
\hline Compounds & Values $^{1}$ \\
\hline Total tocopherol $(\mathrm{mg} / \mathrm{kg})$ & 499.30 \\
$\alpha$-tocopherol & nd \\
$\beta$-tocopherol & $54.00 \pm 1.18$ \\
$\gamma$-tocopherol & $166.60 \pm 2.64$ \\
$\delta$-tocopherol & $278.70 \pm 2.80$ \\
Total phenolic $(\mathrm{mg} / \mathrm{kg})$ & $1,314.13 \pm 14.43$ \\
Antioxidant activity & \\
$\mathrm{DPPH}_{\text {rem }}(\%)$ & $48.00 \pm 0.74$ \\
$\mathrm{EC}_{50}\left(\mathrm{~g} \mathrm{oil} / \mathrm{g}\left[\mathrm{DPPH}^{*}\right]\right)$ & 10.62 \\
$\mathrm{EAR}^{-2}\left(\mathrm{x}^{-2}\right)$ & 9.42 \\
\hline
\end{tabular}

${ }^{1}$ Mean value \pm standard error $(n=3)$.

Regarding phenolic compounds, the concentration found in the passion fruit seed oil $(1,314.13 \mathrm{mg}$ EAG $/ \mathrm{kg})$ was comparable to that found in other vegetable oils, such as oils extracted from blueberry, raspberry and blackberry seeds (Parry et al. 2005). Oliveira et al. (2009) determined the total phenolic concentration in methanol extracts from the passion fruit waste (pulp, skin and seeds) and found $41.2 \mathrm{mg} \mathrm{EAG/g}$ dry extract. According to Haiyan et al. (2007), only a small portion of the seed total phenolics is transferred to the oil during the extraction process.

The percentage of $\mathrm{DPPH}^{*}$ remaining after 30 minute of reaction between the passion fruit seed oil and DPPH $^{\circ}$ was $48 \%$ (Table 4), indicating that the oil presented free radical scavenging activity, i.e., it contained compounds that reacted

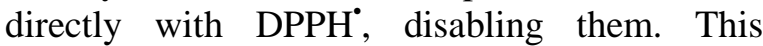
suggested that the oil extracted from the passion fruit seeds could bring benefits if used in feed, fighting free radicals in vivo.

Besides phenolic compounds, tocopherols are natural antioxidants, present in the vegetable oils. According to Schmidt and Pokorný (2005), the $\delta$ - and $\gamma$-tocopherol are more active antioxidants than $\alpha$ - and $\beta$-tocopherol. Therefore, in the passion fruit seed oil, the antioxidant activity appeared to be influenced by the amount of phenolic compounds and the tocopherols composition.

The amount of oil needed to decrease the initial $\mathrm{DPPH}^{\circ}$ concentration by $50 \%\left(\mathrm{EC}_{50}\right)$ was lower than those obtained by Arranz et al. (2008) in the oil extracted from walnut $(1514.3 \mathrm{~g}$ oil $/ \mathrm{g}$ $\left.\left[\mathrm{DPPH}^{*}\right]\right)$, almond (712.2 g oil/g [DPPH $\left.\left.{ }^{*}\right]\right)$, hazelnut (478.5 g oil/g [DPPH']), peanut (1395.9 g oil $\left./ \mathrm{g}\left[\mathrm{DPPH}{ }^{\circ}\right]\right)$ and pistachio nut (377.9 $\mathrm{g}$ oil $/ \mathrm{g}$
$\left.\left[\mathrm{DPPH}^{*}\right]\right)$. This was quite interesting, since the lower the $\mathrm{EC}_{50}$ value resulted the higher the antioxidant oil power. In addition, the passion fruit seed oil antiradical efficiency (EAR) was similar to that found in rice oil $\left(9.37 \times 10^{-2}\right)$ and superior to the oils such as soybean $\left(2.94 \times 10^{-2}\right)$, sunflower $\left(5.92 \times 10^{-2}\right)$, corn $\left(6.76 \times 10^{-2}\right)$ and grape $\left(6.28 \times 10^{-2}\right)$ (Siger, Nogala-Kalucka and Lampart-Szczapa 2008).

\section{CONCLUSION}

From the results it could be concluded that the passion fruit seed oil can be used as raw material in several industries, including food, detergents, cosmetics, vitamin supplements and biodiesel. The significant antioxidant amount may serve as a natural antioxidants dietary source, helping prevent diseases, or as a food additive, increasing the stability and quality of food products. Thus, the extraction of oil from the passion fruit seeds could add value to the products that have been most often disposed as waste, increasing the viable sources of raw materials and reducing the waste.

\section{ACKNOWLEDGEMENTS}

The authors acknowledge FAPESP - Fundação de Amparo à Pesquisa do Estado de São Paulo (process n. 05/54331), CAPES - Coordenação de Aperfeiçoamento de Pessoal de Nível Superior and $\mathrm{CNPq}$ - Conselho Nacional de Desenvolvimento Científico e Tecnológico for their financial support. 


\section{REFERENCES}

AOAC. Official methods of analysis of the Association of Official Analytical Chemists. Arlington: AOAC; 1995.

AOCS. Official methods and recommended practices of the American Oil Chemists' Society. Champaing: AOCS Press; 2003.

Arranz S, Cert R, Pérez-Jiménez J, Cert A, SauraCalixto F. Comparison between free radical scavenging capacity and oxidative stability of nut oils. Food Chem. 2008; 110 (4): 985-90.

Bailey AE. Bailey's industrial oil and fat products. New York: John Wiley; 1996.

Borges SV, Maia MCAM, Gomes RCM, Cavalcanti B. Chemical composition of umbu (Spondias tuberosa Arr. Cam) seeds. Quím Nova 2007; 30 (1), 49-52.

Brand-Williams W, Cuvelier ME, Berset, C. Use of a free radical method to evaluate antioxidant activity. Lebens Wiss Technol. 1995; 28 (1): 25-30.

Codex Alimentarius Commission. Codex-Stan 210: codex standard for named vegetable oils. Rome; 2008.

Del Ré PV. Vegetable oils behavior in discontinued frying of frozen pre fried products [Master's Thesis]. São José do Rio Preto, Brazil: São Paulo State University; 2003.

Dubois V, Breton S, Linder M, Fanni J, Parmentier M. Fatty acid profiles of 80 vegetables oils with regard to their nutritional potential. Eur J Lipid Sci Technol. 2007; 109 (7), 710-32.

El-Adawy TA, Taha KM. Characteristics and composition of different seed oils and flours. Food Chem. 2001; 74 (1): 47-54.

Ferrari RA, Colussi F, Ayub RA. Characterization of by-products of passion fruit industrialization utilization of seeds. Rev Bras Frutic. 2004; 26 (1): 101-2.

Gaydou EM, Ramanoelina ARP. Evaluation of byproducts of the passion fruit juice industry: fatty acid and sterol composition of the seed oil. Fruits 1983; 38 (10): 699-703.

Haiyan Z, Bedgood Jr DR, Bishop AG., Prenzler PD, Robards K. Endogenous biophenol, fatty acid and volatile profiles of selected oils. Food Chem. 2007, 100 (4), 1544-51.

Hartman L, Esteves W. Tecnologia de óleos e gorduras vegetais. São Paulo: Secretaria de Estado da Indústria; 1982.

Hartman L, Lago RCA. Rapid preparation of fatty acid methyl esters from lipids. Lab Pract. 1973; 22: 475-6.
Fraife Filho GA, Leite JBV, Ramos JV. Passion fruit [Internet]. 2010 [updated $2010 \mathrm{Fev}$ 27]. Available from:<http://www.ceplac.gov.br/radar/maracuja.ht $\mathrm{m}>$.

Kalantzakis G, Blekas G, Pegklidou K, Boskou D. Stability and radical-scavenging activity of heated olive oil and other vegetable oils. Eur J Lipid Sci Technol 2006; 108 (4): 329-35.

Lásztity R. The chemistry of cereal proteins. Boca Raton: CRC Press; 1996.

Liu S, Yang F, Li J, Zhang C, Ji H, Hong P. Physical and chemical analysis of Passiflora seeds and seed oil from China. Int J Food Sci Nutr 2008; 59 (7-8), 706-15.

Lousada Júnior JE, Costa JMC, Neiva JNM, Rodriguez NM. Physical-chemical characterization of tropical fruit by-products for use in animal feed. Rev Ciênc Agron. 2006; 37 (1): 70-6.

Meletti LMM, Soares-Scott MD, Bernacci LC. Phenotypic characterization in three selections of purple passion fruit (Passiflora edulis Sims). Rev Bras Frutic. 2005; 27 (2): 268-72.

Nyanzi SA, Carstensen B, Schwack W. A comparative study of fatty acid profiles of Passiflora seed oils from Uganda. J Am Oil Chem Soc. 2005; 82 (1): 41-4.

Oliveira AC, Valentim IB, Silva CA, Bechara EJH, Barros MP, Mano CM, Goulart MOF. Total phenolic content and free radical scavenging activities of methanolic extract powders of tropical fruit residues. Food Chem. 2009; 115 (2): 469-75.

Parry J, Su L, Luther M, Zhou K, Yurawecz MP, Whittaker P, Yu L. Fatty acid composition and antioxidant properties of cold-pressed marionberry, boysenberry, red raspberry, and blueberry seed oils. J Agric Food Chem. 2005; 53 (3): 566-73.

Piombo G, Barouh N, Barea B, Boulanger R, Brat P, Pina M, Villeneuve P. Characterization of the seed oils from kiwi (Actinidia chinensis), passion fruit (Passiflora eulis) and guava (Psidium guajava). Oléagineux, Corps Gras, Lipides 2006; 13 (2-3): 195-9.

Sant'Anna ES, Tôrres RCO, Porto ACS. Evaluation of different chromatographic methods for the fatty acids determination of passion fruit seeds (Passiflora edulis f. flavicarpa). B. CEPPA 2001; 19 (1): 85-94.

Schmidt S, Pokorný J. Potential application of oilseeds as source of antioxidants for food lipids - a review. Czech J Food Sci. 2005; 23 (3): 93-102.

Siger A, Nogala-Kalucka M, Lampart-Szczapa E. The content and antioxidant activity of phenolic compounds in cold-pressed plant oils. J Food Lipids 2008; 15 (2): 137-49. 
Singleton VL, Rossi JA. Colorimetry of total phenolics with phosphomolybdic and phosphotungstic acid reagents. Am J Enol Vitic 1965; 16 (3): 144-58.

Sousa CMM, Silva HR, Vieira-Jr GM, Ayres MCC, Costa CLS, Araújo DS, et al. Total phenolics and antioxidant activity of five medicinal plants. Quim Nova 2007; 30 (2): 351-5.
Tuberoso CIG, Kowalczyk A, Sarritzu E, Cabras P. Determination of antioxidant compounds and antioxidant activity in commercial oilseeds for food use. Food Chem. 2007; 103 (4): 1494-501.

Received: November 23, 2010; Revised: February 18, 2011; Accepted: November 07, 2011. 